\title{
Changes in the Density of the Particle Mass of Diverse Kinds of Hay Incubated in the Rumen of Sheep Given Oat Hay as Their Sole Diet
}

\author{
JIN HAI, Katsumi HAMANA') and Junjiro SEKINE ${ }^{2)}$ \\ The United Graduate School of Veterinary Sciences, Yamaguchi University, \\ Yamaguchi-shi 753 \\ ${ }^{1)}$ Faculty of Agriculture, Kagoshima University, Kagoshima-shi 890 \\ 2) Faculty of Agriculture, Tottori University, Tottori-shi 680
}

(Received July 17, 1996)

\begin{abstract}
To determine changes in the true density and specific gravity of the dietary particle mass and the bulk density of forages in the course of ruminal fermentation, seven kinds of hay were incubated in situ in the rumen of sheep given oat hay as their sole diet. The true density of the forage ranged from 1.6 to $1.8 \mathrm{~g} / \mathrm{ml}$ and showed no change with incubation time. The fractional specific gravity of the samples increased from around $0.7 \mathrm{~g} / \mathrm{m} l$ at the start of incubation to about $1.3 \mathrm{~g} / \mathrm{m} l$ at $2 \mathrm{~h}$ after incubation, and then stayed at nearly a constant level up to $96 \mathrm{~h}$ of the incubation time. The bulk density of the forage particulates changed a little within $4 \mathrm{~h}$ incubation, and thereafter decreased to about $70 \%$ of the original density after $24 \mathrm{~h}$ of incubation without significant change for up to $96 \mathrm{~h}$ of incubation. The degradation pattern of neutral detergent fiber was similar to the change in bulk density. A significant correlation was found between them $(P<0.01)$. It was concluded that bulk density was related to the digestion of fibrous fraction through a change in the conformation of the forage particles. The true density and functional specific gravity, however, were not related.
\end{abstract}

Anim. Sci. Technol. (Jpn.) 67 (12) : 1068-1075, 1996

Key words : True density, Functional specific gravity, Bulk density, NDF degradation, Forage

Feed is a source of nutrients for animals. The control of feed intake, therefore, determines the production response of farm animals. The feed intake of ruminants has been believed to be governed by chemical and physical factors. For bulky feeds such as forage for ruminants, the limiting factors for feed intake are the digestion rate of fibrous fractions and the physical properties of the feed associated with the fill of the digestive tract concerned. The dry bulk density of diverse kinds of hay has been found to be one of controlling factors for forage intake by cows and sheep given hay as a sole diet ${ }^{2.4}$. However, the bulk density merely shows the physical space of the rumen to be occupied by the ingested feed. The physical properties of forage other than the bulk density, therefore, need to be considered. The passage rate of the ingesta also is related to the ruminal fill of ruminants given forage. The specific gravity of the ingesta in the rumen may be one of factors that controls the rate of the passage of particulates as has been reported ${ }^{1)}$, although the particles should be reduced particle size to the extent possible to pass through the reticulo-omasal orifice ${ }^{6)}$.

The present study was carried out to determine what underlies in the changes in the specific gravity of the dietary particle mass in the course of ruminal fermentation. 


\section{Materials and Methods}

Four Corriedale wethers $(33.4 \pm 7.5 \mathrm{~kg}$ live weight) with ruminal cannulae were given oat hay at a maintenance level in two equal portions twice daily for 14 days as a preliminary period after an adaptation period of about 1 month. Following the preliminary period, samples of 7 kinds of hay : alfalfa (AL), bermuda grass ( $B G)$, Italian ryegrass (IR), oats (OA), perennial ryegrass (PR), sudan grass (SG) and timothy (TI) were incubated in the rumen for 0 , $2,4,8,12,24,48$ and 96 hours by using the nylon bag technique. The bags (pore size, $45 \mu \mathrm{m}$; bag size, $100 \times 200 \mathrm{~mm}$ ) were filled with $8 \mathrm{~g}$ of samples of each hay cut through an $8 \mathrm{~mm}$ screen and a stainless steel ball (about $33 \mathrm{~g}$ ) as a weight. Before incubation started, bags were immersed into Burrough's solution for $1.5 \mathrm{~min}$. with gentle massaging to eliminate excess air in the samples. Two bags were fixed to a $2 \times 7$ $-\mathrm{cm}$ silicone tube with a $10-\mathrm{cm}$ fishing line (No. 8 ; standard diameter, $0.471 \mathrm{~mm}$ ) to connect to the cover of cannulae. Six bags were incubated simultaneously. For incubation of bags for 2 and 4 hours, the care was taken not so as to coincide with 2 hours before or after the feeding of diets. After incubation, the bags were washed with tap water for $3 \mathrm{~min}$. to eliminate ruminal residues on the bag. The pycnometer was specially prepared by the use of a $200-\mathrm{m} l$ boiling flask with flattened bottoms so as to accommodate incubated samples. Incubated samples in the bag were totally evacuated into the $200-\mathrm{m} l$ pycnometer. The pycnometer was warmed to $38^{\circ} \mathrm{C}$ for $5 \mathrm{~min}$. and weighed to determine the functional specific gravity (F sp. gr.). Then, the pycnometer was placed under a vacuum of $35 \mathrm{~mm} \mathrm{Hg}$ for $10 \mathrm{~min}$. and was then weighed again at $38^{\circ} \mathrm{C}$ to determine the true density of particulate mass. Incubated samples were determined for dry matter (DM), and bulk density was then measured using a $100-\mathrm{m} l$ glass cell under pressure applied at the rate of $10 \mathrm{~g} / \mathrm{cm}^{2}$. Neutral detergent fiber (NDF) was determined by air-dried incubated samples ground through a $1 \mathrm{~mm}$ screen after measurement of the bulk density.

\section{Results and Discussion}

Table 1 shows the chemical composition of hays used for incubation in the rumen of sheep given oat hay as a sole diet. The crude protein contents of the IR, OA, PR, SG and TI hays were less than $10 \%$ of DM. The fibrous fractions were fairly similar among grass hays except for $\mathrm{OA}$ in which the fibrous fractions were contained less than the others. Also AL tended to contain less fibrous fractions in which hemicellulose was contained about half

Table 1. Chemical composition of hays used for incubation in the rumen of sheep

\begin{tabular}{|c|c|c|c|c|c|c|c|}
\hline & $A L^{\mathrm{D}}$ & BG & $\mathrm{IR}$ & OA & PR & $\mathrm{SG}$ & $\mathrm{TI}$ \\
\hline & & & - & \multirow{2}{*}{$\begin{array}{c}\% \text { as is } \\
92.5\end{array}$} & - & - & 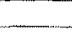 \\
\hline Dry matter & 92.9 & 93.1 & 92.3 & & 92.8 & 91.0 & 92.9 \\
\hline Crude protein & 12.7 & 10.7 & 7.6 & 6.7 & 5.3 & 8.5 & 4. 4 \\
\hline NDF & 49.4 & 74.4 & 74.9 & 57.5 & 69.0 & 69.7 & 72.9 \\
\hline ADF & 39.2 & 38.9 & 49. 1 & 32.7 & 42.4 & 41.0 & 46.8 \\
\hline ADL & 3.8 & 5.0 & 5.3 & 3.6 & 5.2 & 3.4 & 6.8 \\
\hline Cellulose & 31.4 & 33.9 & 43.8 & 29.1 & 37.2 & 37.6 & 40.0 \\
\hline Hemicellulose & 10.2 & 35.5 & 25.8 & 24.8 & 26.6 & 28.7 & 26.1 \\
\hline
\end{tabular}

1) Abbreviated notations are as follows : AL, alfalfa hay ; BG, Bermuda grass hay ; IR, Italian ryegrass hay ; $O A$, oats hay; PR, perennial ryegrass hay; SG, sudan grass hay ; TI, timothy hay; NDF, neutral detergent fiber ; $A D F$, acid detergent fiber and $A D L$, acid detergent lignin. 
of the other hays.

Fig. 1 shows changes in the true density of the forage particulates examined in the present study. True density was similar among the hays ranging from 1.6 to $1.8 \mathrm{~g} / \mathrm{m} l$ and did not change with the incubation time irrespective of the kinds of hay. Gases in the inner voids formed within the particles by microbial fermentation are inferred to be evacuated and replaced by liquid by the application of a vacuum. Siciliano-Jones and Murphy ${ }^{3)}$ found that the true specific gravity determined by centrifuging various feedstuffs ranged from 1.3 to 1.5 and showed no significant difference among feedstuffs or particle sizes. Results in the present study agreed well with their findings, although our method for measuring true density differed from theirs. Thus, it is inferred that the true density of forages is essentially the same among forages with a little variation irrespective of the kinds of hay.

The $\mathrm{F}$ sp. gr. at $0 \mathrm{~h}$ incubation ranged from 0.6 to $0.8 \mathrm{~g} / \mathrm{m} l$ among the kinds of hay. The $F$ sp. gr. for AL, OA, PR and TI hays increased to 1.2 to $1.4 \mathrm{~g} / \mathrm{ml}$ after $2 \mathrm{~h}$ of incubation, and then stayed at about a constant level for the remainder of the incubation time. Those for BG, IR and SG increased gradually to about $1.2 \mathrm{~g} / \mathrm{m} l$ up to $24 \mathrm{~h}$ of incubation. The particles escaped from the rumen have been found to have $1.2 \mathrm{~g} / \mathrm{m} l$ or more of $\mathrm{F}$ sp. $\mathrm{gr}^{7)}$. The particulates of hays examined in the present study, therefore, may have reached a possible $\mathrm{F}$ sp. gr. to pass through the rumen after $2 \mathrm{~h}$ of incubation except for BG, IR and SG which may rcquire more time to reach it. Thereafter, ruminal fermentation may not have influence upon changes in the F sp. gr. of forage particulates. The results were inconsistent with those obtained by Wattiaux et $a l^{6}{ }^{6}$ in the study by incubation in vitro in which the $\mathrm{F}$ sp. gr. of alfalfa hay particles decreased from $3 \mathrm{~h}$ to $9 \mathrm{~h}$ of the incubation period, then increased up to $27 \mathrm{~h}$ of incubation, and thereafter stayed at a constant level up to $30 \mathrm{~h}$. They inferred that an increase in $F$ sp. gr. was resulted from the exceeded escape of gas over the formation of gas bubbles in particles due to the decreased gas production from $6 \mathrm{~h}$ to $27 \mathrm{~h}$ of incubation. Feed particles incubated in situ may be subjected to considerable pressure and abrasion by the continuous movement of the rumen. This may cause the rapid hydration of the inner voids formed by the microbial fermentation of particles, which thereby results in an increase in the F sp. gr. of particles. Therefore, particles incubated in the rumen may reach a constant $F$ sp. gr. in an earlier time than those incubated in vitro. The level reached at a plateau agreed well between the present study and the in vitro study $y^{6)}$ irrespective of kinds of hay. Wattiaux et al..$^{5)}$ reported that in situ incubation in the rumen changed the distribution of residual dry matter with a given specific gravity within $4 \mathrm{~h}$. Their results, however, showed no major shift of dry matter from one fraction of specific gravity to another from 4 to $96 \mathrm{~h}$ of incubation. This implies that a major change in specific gravity of particulates occurs within $4 \mathrm{~h}$ incubation time for alfalfa hay, alfalfa silage and corn silage ${ }^{5)}$. This implication is consistent with the results obtained for AL, OA, PR and TI in the present study.

Changes in the bulk density of diverse kinds of hay were presented in Fig. 2. The bulk density of the grass hay particulates ranged from 0.07 to $0.09 \mathrm{~g} / \mathrm{m} l$ and that of the alfalfa hay was $0.12 \mathrm{~g} / \mathrm{ml}$. The bulk density of forages showed little change within $4 \mathrm{~h}$ of incubation. After 24 $\mathrm{h}$ of incubation, it decreased to about $70 \%$ of the original density, but it showed a small change for the rest of the incubation time. Changes in the volume of the residual drymatter that were obtained in the in vitro study ${ }^{5)}$ showed a similar tendency except after $4 \mathrm{~h}$ to 6 $\mathrm{h}$ of incubation, which started to decrease $\mathrm{e}^{5)}$. It is assumed, therefore, that the conformation of the forage particles may not change until the structural carbohydrates begin to be degraded by the microbial activity. The structural car- 
Changes in the Density of Hay Particle Mass in the Rumen

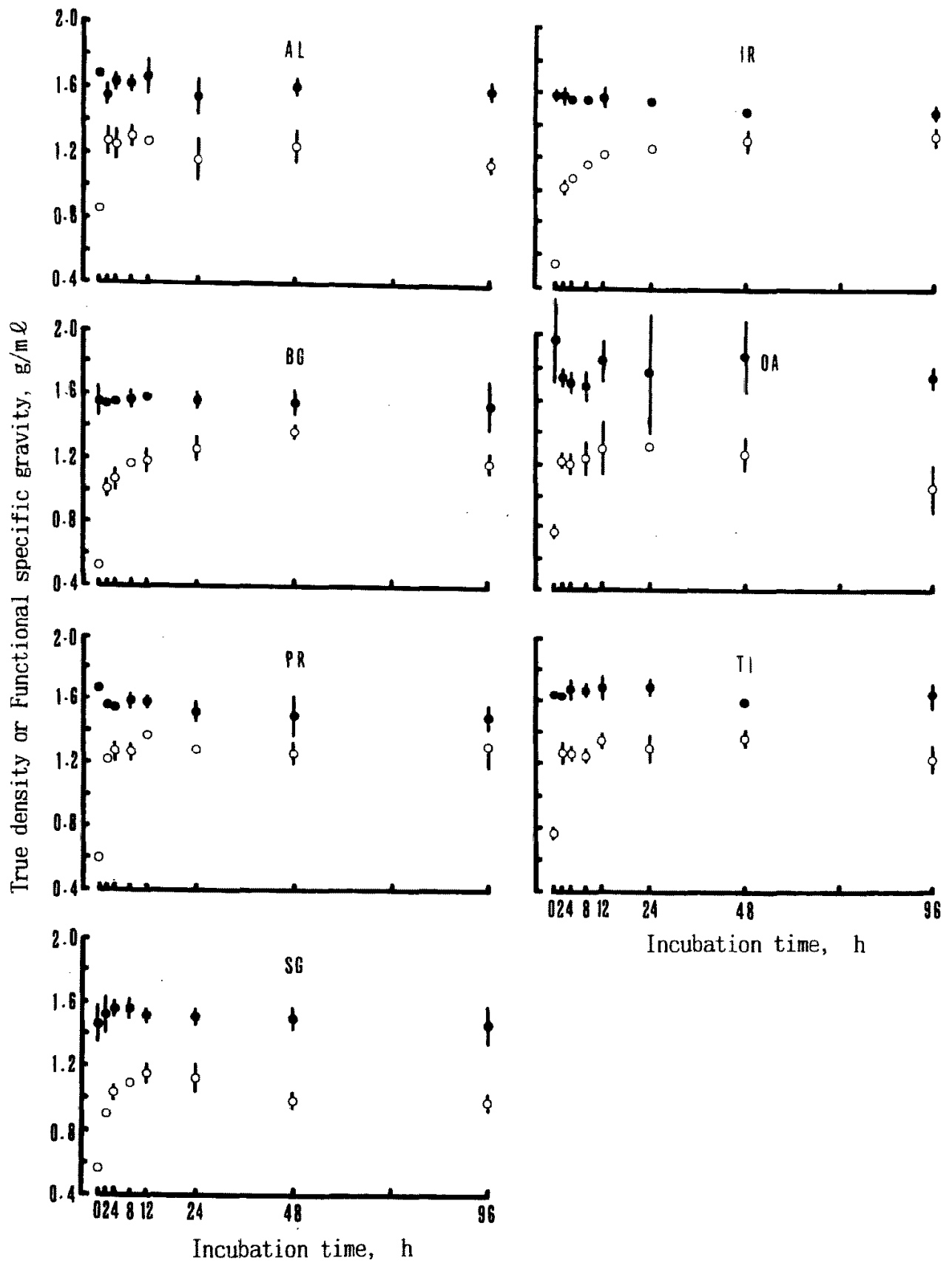

Fig. 1. Changes in the true density and the functional specific gravity of the particulates of diverse kinds of hay incubated in the rumen of sheep.

Abbreviated notations for kinds of hay are shown in the text.

Cach solid circle with the vertical bar shows mean true density of four sheep with the standard deviation at each incubation time. Each open circle represents mean functional specific gravity of four sheep with the standard deviation at each incubation time. 
JIN HAI, HAMANA and SEKINE
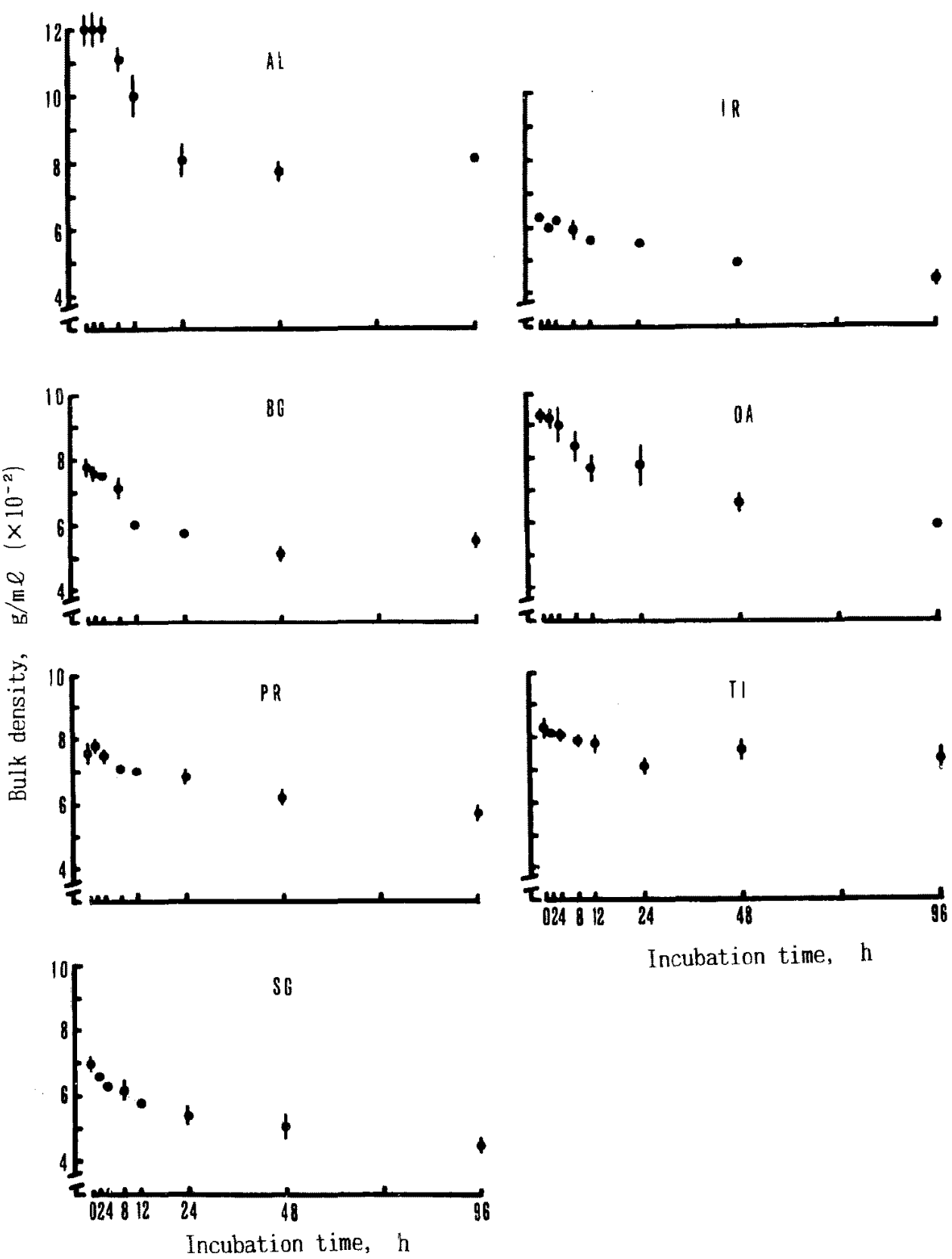

Fig. 2. Changes in the bulk density and the particulates of diverse kinds of hay incubated in the rumen of sheep.

Abbreviated notations for kinds of hay are shown in the text.

Each solid circle with the vertical bar shows mean of four sheep with the standard deviation at each incubation time. 
Changes in the Density of Hay Particle Mass in the Rumen

bohydrates mainly consist of NDF. Thus, main factor controlling rigidity or fragility of brittleness of NDF may be speculated to be a forage particles.

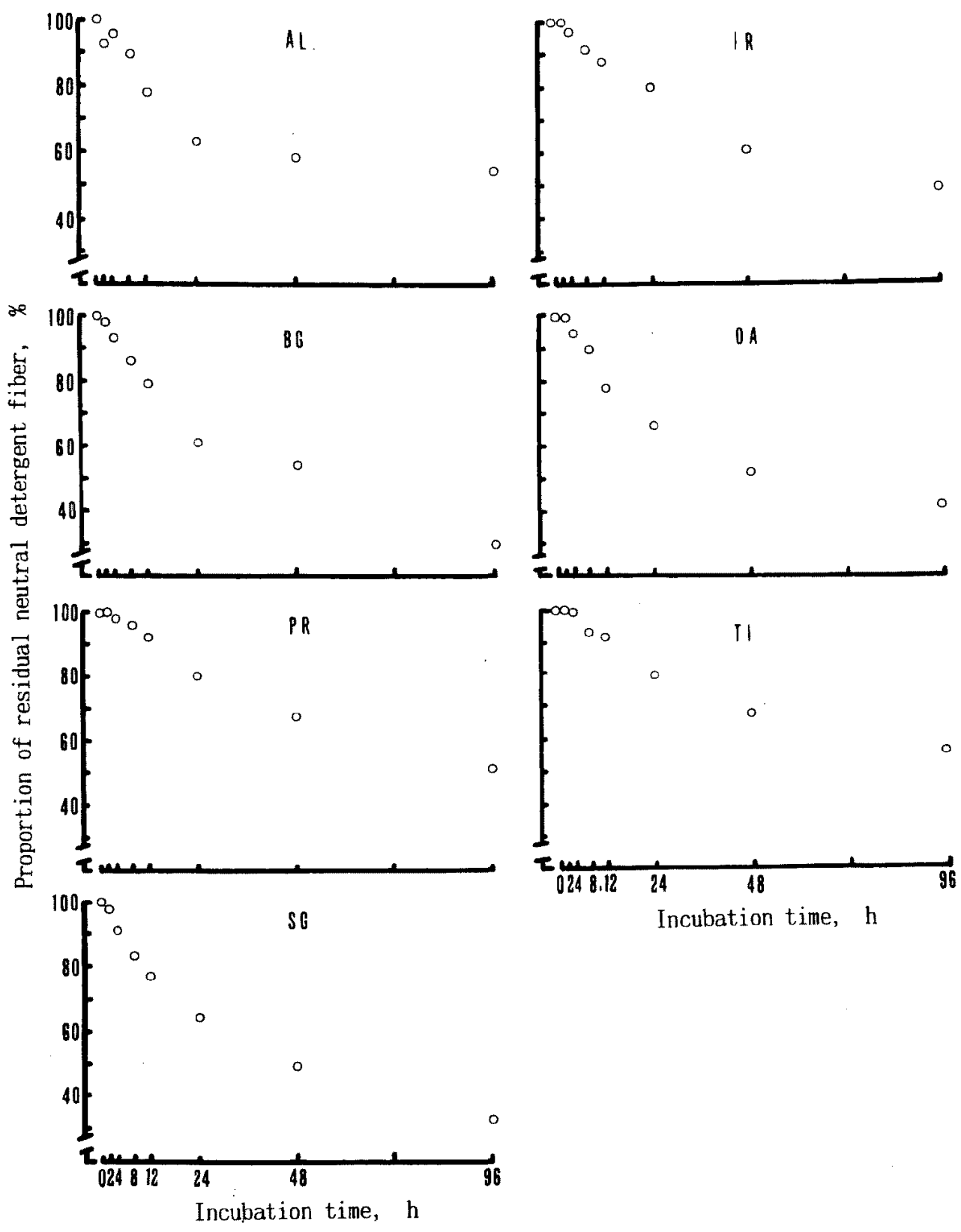

Fig. 3. Changes in residual neutral detergent fiber of particulates of diverse kinds of hay incubated in the rumen of sheep.

Abbreviated notations for kinds of hay are shown in the text.

Each open circle shows mean of four sheep. 
The changes in residual NDF revealed that its degradation appeared to begin after $4 \mathrm{~h}$ of incubation (Fig. 3). As a significant relationship was assumed between changes in the bulk density of residual hay particulates and their NDF degradation pattern in the present study, the correlation coefficients between them were calculated. The results revealed that there was a significant correlation between the proportion of residual NDF and the bulk density of the residual particulates for each hay as follows: $\mathrm{AL}, \mathrm{r}=0.983 ; \mathrm{BG}, \mathrm{r}=0.926 ; \mathrm{IR}, \mathrm{r}=$ $0.983 ; \mathrm{OA}, \mathrm{r}=0.982 ; \mathrm{PR}, \mathrm{r}=0.970 ; \mathrm{SG}, \mathrm{r}=0.984$ and $T I, \quad r=0.800 \quad(P<0.01), \quad$ respectively. Changes in the F sp. gr. in the forage particle mass did not show any significant relation to NDF degradation, although the F sp. gr. tended to increase as the proportion of residual NDF decreased $(r=-0.063 \sim-0.341)$. Provided it is correct that the buoyancy effect of gases of fermentation is a potent discriminator in extent of digestion as suggested from in vitro experiment by Wattiaux et al. ${ }^{6}$, the effect of gases may be considerably reduced because gases produced by ruminal fermentation would be evacuated from a particle by vigorous ruminal movement in vivo. Thus, from the results obtained in the present study, it is not speculated that the NDF degradation is related to the change in $\mathrm{F}$ sp. gr. of particulates in the rumen.

The true density of the particulates did not show any significant correlation to the proportion of residual NDF $(r=-0.003 \sim 0.184)$. These results support the above assumption because particles were completely evacuated fermentation gas.

From the results and the discussion above, we conclude that the true density of a forage particle mass is a factor that by no means affects the kinetics of the particulates in the rumen. The $\mathrm{F} \mathrm{sp.} \mathrm{gr.} \mathrm{of} \mathrm{the} \mathrm{particle} \mathrm{mass} \mathrm{of}$ the digesta in the rumen may be little related to the digestion of fibrous fractions, if any. Changes in the bulk density of the ingested hay may be a factor that affects forage intake concurrently with NDF digestion, although the rate of ruminal passage was not considered in the present study.

\section{References}

1) deBordes CK, Welch JG. Influence of specific gravity on rumination and passage of indigestible particles. J. Anim. Sci., 59 : 470-475. 1984.

2) Sekine J, Ueda J, Jin Hai, Kamel HEM, Oura R, Morita Z. Effects of chemical and physical characteristics of forage on dry-matter intake of cattle. Ann. Zootech., 44 (Suppl. 1) : 253. 1995.

3) Siciliano-Jones J, Murphy MR. Specific gravity of various feedstuffs as affected by particle size and in vitro fermentation. J. Dairy Sci., $74: 896-901.1991$.

4) Tomari T, Kamel HEM, Jin Hai, Oura R, Sekine $J$. Effects of crude protein, neutral detergent fiber, dry bulk density, and brittleness of the hay on feed intake of sheep. Jpn. J. Sheep Sci., 32: 7-13. 1995.

5) Wattiaux MA, Mertens MD, Satter LD. Effect of source and amount of fiber on kinetics of digestion and specific gravity of forage particles in the rumen. J. Dairy Sci., $74: 3872-3883$. 1991.

6) Wattiaux MA, Satter LD, Mertens MD. Effect of microbial fermentation on functional specific gravity of small forage particles. J. Anim. Sci., $70: 1262-1270.1992$.

7) Welch JG. Physical parameters of fiber affect" ing passage from the rumen. J. Dairy Sci., 69 : 2750-2754. 1986. 


\title{
オーツヘイ単独給与めん羊の反㫚胃内で培養した 種々の乾草粒子の密度変化
}

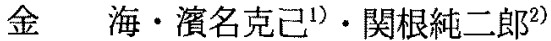 \\ 山口大学大学院連合獣医学研究科, 山口市 753 \\ 1) 鹿児島大学農学部，鹿児島市 890 \\ 2) 鳥取大学農学部, 鳥取市 680
}

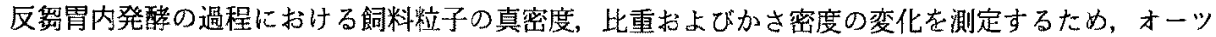

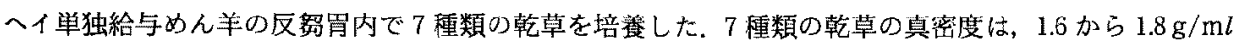
の範国にあり，培養時間による違いは認められなかった，乾草の実効此重は，培養開始時の $0.7 \mathrm{~g} / \mathrm{m} l$ 汃 ら培養 2 時間後の約 $1.3 \mathrm{~g} / \mathrm{ml}$ まで增加した。その後は、ほぼ一定の水準で培養 96 時間まで推移した。乾 草粒子のかさ密度は，培養 4 時間まではほとんど変化が認められなかったが，その後，培養 24 時間まで にもとの值の $70 \%$ まで減少した．それ以降は培養 96 時間まで著しい恣化は認められな加った，中性デ タージェント瀻維の分解様相は，かさ密度の变化之同様であった．この両者には，有意な相関関係が認 められた $(\mathrm{P}<0.01)$. かさ密度は, 乾草粒子の構造との関連により䄉維分画の消化過程と関係している と結諭された。しかしながら，乾草の真密度抢よび実効比重は，繊維分画の消化過程とは関連がない 推察された。
\end{abstract}

日畜会報，67 (12) : 1068-1075, 1996 